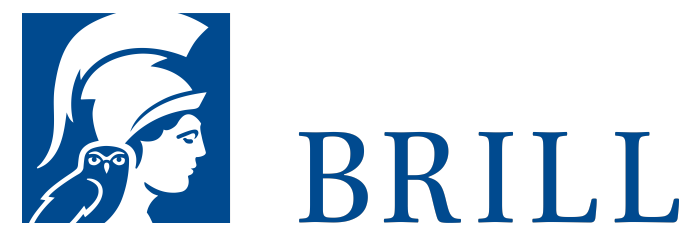

\title{
The It Factor: What Makes a Teacher Great?
}

\section{Author: Holly J. Thornton}

The impact a teacher has on students may be profound and lasting. Thus, teacher preparation is grounded in standards to assure that all teacher candidates know the content and have the skills needed to become good teachers. What makes a teacher great? The answer is not clear-cut or easily measured with tests. But we all know a great teacher when we see one. The best teachers have an It Factor that sets them apart from others. It is seemingly intangible and unteachable, as it's often said that, "Some people are just born to be teachers." This book challenges that assumption and uncovers the It Factor. Teacher and student voices helped to develop language and tools to examine how teachers are disposed to think and act and how this affects student learning. If we can identify what makes teachers great, we can teach it.

Students have a sea of information, opinions and messaging at their fingertips. They find themselves navigating through a myriad of facts and "alternative facts." Opinions, beliefs, and fallacies share the same platform and status as well grounded information and vetted ideas, fueling tensions among individuals and distance between groups. Developing students who are caring, critical thinkers and problem-solvers may be more important now than ever. The teachers who are right for this challenge have more than content knowledge and teaching skills. To meet this...

See More

Readership

Anyone concerned with teacher quality and preparing students as empathetic, ethical, and thinking leaders can benefit from considering the importance and cultivation of educator dispositions this book illustrates and assesses.

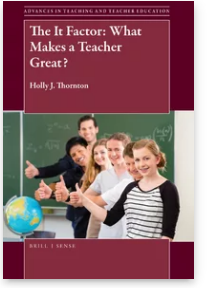

Language:

English

Subjects:

General,

Education,

Teacher

Education,

Education,

Professional

Development,

Education

Publisher: Brill

Series:

Advances in

Teaching and

Teacher

Education,

Volume: 2

E-Book (PDF)

Released online: 16 May 2018

ISBN: 978-90-

o4-36448-6

List price

USD \$130.0o

Hardback

Publication date:

22 Mar 2018

ISBN: 978-90-

04-36447-9

List price

USD \$130.0o 
Publication date:

15 Mar 2018

Holly J. Thornton is a National Board Certified teacher who earned her PhD in educational leadership at the Ohio State University. She has evaluated multiple teacher preparation programs nationally as a program reviewer and member of the ISBN: 978-90o4-36446-2 List price NCATE Board of Examiners. Her research employs using multiple lenses to examine quality education.

For more information see brill.com

Order information: Order online at brill.com +44330 3330049 | customerservices@brill.com Submission information: brill.com/authors

Titles published by Brill | Fink, Brill | mentis or Brill | Schöningh: +49(o)71 5413279216 | brill@brocom.de 